\title{
Internaattiyhteisö pedagogisena mahdollisuutena
}

\begin{abstract}
Heikki Sederlöf: Sisäoppilaitostutkimus. Opetusministeriön työryhmän muistioita 1984:41.
\end{abstract}

Heikki Sederlöfin Sisäoppilaitostutkimus on vuoden 1979 kansanopistotoimikunnan aloitteesta syntynyt ns. toimeksiantotutkimus, joka ilmestyi vuoden 1986 alussa. Tutkimuksen pääasiallinen rahoittaja on ollut opetusministeriö ja toimeenpanija Suomen Kansanopistoyhdistys. Kysymyksessä on siis kansanopiston sisäoppilaitosluonnetta käsittelevä tutkimus.

Kansanopiston internaattimuotoa on perinteisesti pidetty kansanopistolaitoksen tunnusomaisena piirteenä ja sen pedagogista merkitystä on jatkuvasti korostettu. Vuoden 1979 kansanopistotoimikunnan mukaan kansanopiston sisäoppilaitosluonnetta voidaan pitää jopa toiminnan välttämättömänä ehtona (s. 1). Toisaalta kansanopiston sisäoppilaitosluonnetta on kuitenkin varsin vähän tutkittu, eikä näin ollen ole systemaattista kuvaa siitä, mitä internaattimuoto pedagogisena elementtinä merkitsee, miten sitä voidaan parhaiten hyödyntää, mitä ongelmia siihen liittyy jne. Tästä syystä vuoden 1979 kansanopistotoimikunta katsoi tarpeelliseksi käynnistää sisäoppilaitostotutkimuksen, "'joka on tarkoitettu antamaan ainakin joitakin viitteitä siitä, miten kansanopistoa voitaisiin kehittää käyttäen hyväksi sen sisäoppilaitosmuotona tarjoamia pedagogisia mahdollisuuksia" (s. 10). Tutkimuksella on varsin konkreettinen lähtökohta ja käytännöllinen tavoite: on haluttu tietoa joka palvelee käytäntöä ja kansanopiston kehittämistä.

Edellä esitetystä lähtökohdasta käsin on tutkimukselle asetettu muutamia keskeisiä periaatteita ja vaatimuksia, jotka rajaavat tarkasteluperspektiiviä ja voimakkaasti suuntaavat myös metodista otetta. Koska ko. periaatteilla on ollut tutkimuksen ongelmanasettelun ja toteutuksen kannalta ratkaiseva merkitys, tarkastellaan niitä tässä lähemmin. Keskeisimmät periaatteet ovat seuraavat (s. 10-11):

1. "Ongelmien tulee olla ylipäätään empiirisesti tutkittavissa, so. jollakin tapaa käytännöllisesti mitattavissa - vaikka vain yleiselläkin tasolla.

2. Ongelmiin vastaamiseen tulee tuottaa sovellettavissa olevaa (pedagogisen kehittelytyön lähtökohdaksi kelpaavaa) käyttökelpoista tietoa mahdollisimman pienin kustannuksin. Tutkimuksen käytännönläheinen selvitysluonne siis korostuu ongelmien muotoilussa.

3. Ongelmien tulee olla tutkimuksen teoreettisen taustan puuttumisen vuoksi mahdollisimman selkeitä käsitteistöltään. Ongelmat tulee voida muotoilla konkreettisiksi ja selkeiksi opiston arkitodellisuuteen liittyviksi kysymyksiksi. Samalla tulee kuitenkin mahdollistaa operationalisoinnin taakse ulottuva johtopäätösten teko, ainakin jonkinasteinen konkreettisten kysymysten yli ulottuva opistojen toiminnan tarkastelu."

4. "’Ongelmia tulee voida lähestyä niin, etteivät tutkimuksen kohteena olevien opistojen opettajat tai opiskelijat tutkimuksen toimeenpanon takia ainakaan kovin suuressa määrin pyri muuttamaan käyttäytymistään tai pyri antamaan itsestään/opistostaan tiettyä tarkoituksellista kuvaa."

Näistä lähtökohdista tutkimuksen toteutustapaa on vahvasti rajattu positivistis-empiristisen tutkimusperinteen mukaisesti. Kahteen ensimmäiseen periaatteeseen sisältyvä ilmeinen harhaoletus on, että empiirinen tutkimus ollakseen käytäntöä palvelevaa merkitsee sitä, että tutkittavat asiat tulee olla mitattavissa. Tässä tutkimuksessa tehty ratkaisu on merkinnyt sitä, että empiirinen tieto kansanopistojen johtokunnilta, opettajilta ja opiskelijoilta on hankittu perinteisillä "rastiruutuun" -kyselylomakkeilla. Tutkimuksen lähtökohtia ja tavoitteita esiteltäessä ei problematisoida sitä, minkä tyyppistä käytäntöön sovellettavissa oleva tieto on ja missä muodossa se tulisi esittää. Kun tutkimus on lähtenyt liikkeelle kansanopiston sisäoppilaitosmuodon kehittämistarpeesta voimakkaasti käytännöllisiä näkökohtia painottaen - mikä sinänsä on aivan perusteltua - olisi ollut sekä toimeksiantajan että tutkijan aihetta pohtia, minkä tyyppinen tieto palvelee käytäntöä ja millä tavalla. 
Toimeksiantotutkimusten erityisluonteeseen kuuluu yleensä se, että tutkimuksen tilaaja määrittää ne reunaehdot, joiden puitteissa toimitaan. Ilmeisesti myös tämän tutkimuksen toteutustapa on määräytynyt toimeksiantajan ehdoilla. Edellä esitettyjen periaatteiden lisäksi on vielä edellytetty ns. 'kovaa' aineistoa, minkä vuoksi pääasiallisena tiedonkeruumenetelmänä on käytetty strukturoitua kyselyä. Tämän rajauksen pohjalta tulee jollakin tavalla ymmärrettäväksi edellä esitetty 4. periaate, jonka mukaan tutkimus ei saisi vaikuttaa siihen arkikäytäntöön ja työhön, jota opettajat ja opiskelijat kansanopistoissa tekevät. Toisaalta kuitenkin tutkimuksen keskeisenä motiivina on ollut juuri käytännön kehittäminen. Tästä kohoaa välttämättä yksi tämän tyyppisiin tutkimuksiin liittyvä paradoksi: tutkijan pitäisi toisaalta olla tutkimuskohteensa puolueeton päältäkatsoja, joka ei ota kantaa eikä pyri muuttamaan kohdettaan, mutta toisaalta tutkimuksen pitäisi juuri tätä tehdä, so. vaikuttaa käytännön kehittämiseen. Tilanne päättyy tavallisesti siihen, että tutkimusraportin julkaisemisen jälkeen jokainen saa 'soveltaa' tietoja oman makunsa ja tarpeensa mukaan. Yleensä kukaan ei sovella!

Tässä tutkimuksessa toteutetun ratkaisun vaihtoehtona olisi voinut olla esimerkiksi toimintatutkimuksen idealle rakentuva menettely, jossa myös olisi lähdetty liikkeelle kansanopistojen sisäoppilaitosmuodon kehittämistavoitteesta, mutta kehittelytyö olisi tapahtunut (tai pantu hyvälle alulle) tutkimusprosessin aikana. Tähän olisi kansanopistoissa ollut myös erinomaiset mahdollisuudet verrattuna esim. peruskouluun tai lukioon. Kansanopistothan voivat pedagogisen vapautensa vuoksi joustavasti järjestellä opetustaan ja siten myös kokeilla ja kehitellä si- säoppilaitosmuodon tarjoamia mahdollisuuksia.

Mikäli tutkimuksen lähtökohdiksi esitetyt periaatteet ja toteutustapa hyväksytään, voidaan sisäoppilaitostutkimusta pitää huolellisesti tehtynä työnä. Tutkimuksessa on itse asiassa myös hyvin tiedostettu toteutustapaan liittyvät rajoitukset ja ongelmat. Kriittisen ja perusteellisuuteen pyrkivän tutkimuksen yllättävänä puutteena voidaan kuitenkin pitää teoreettisen perustan niukkuutta ja hataruutta. Tutkimuksessa todetaan, ettei kansanopistojen sisäoppilaitosmuotoisuutta koskevaa teoreettista kehittelyä ole varsinaisesti olemassa. Tämä pitää kyllä paikkansa, mutta toisaalta kansanopistoakin koskevaa ja aihetta sivuavaa tutkimusta on siinä määrin, että aineksia teoreettisen viitekehyksen rakentamiseksi olisi ollut.

Teoreettisten tarkastelujen puuttumiselle saattaa olla toinenkin syy - joka on tässä ehkä ilmeisempi: hallinnon tarpeita palvelevien toimeksiantotutkimusten yleiskuva on ollut, että niissä on syytä karttaa teoreettisia tarkasteluja. Tutkimuksen tilaajat haluavat 'empiiristä faktaa', ei teoreettisia analyyseja. (Käytännön ohjeena onkin usein ollut, että viimeistään raportointivaiheessa tulisi 'teoreettinen tausta' jättää mahdollisimman vähälle.) Teoreettisen perustan puutteilla on tässä työssä ollut selvät seurauksensa. Koska tutkimuksessa ei ole teoreettisesti jäsennetty mitattavaa käsitteistöä, on kyselylomake rakennettu ilmeisesti jonkinlaisen käytännön tuntuman ja ns. asiantuntijoiden mielipiteiden pohjalta. Näin ollen tiedonkeruulomakkeissa onkin kysytty lähes kaikkea mahdollista, mitä kansanopistosta voidaan kysyä.

Kyselylomakkeet tosin heijastavat johdonmukaisesti jo tutkimuksen lähtökohdissa omaksuttua näkemystä kasvatustutkimuksen luonteesta.
Otettakoon yksi esimerkki. Opettajien työskentelyä opistoissa on kartoitettu mm. seuraavantyyppisillä muuttujilla: '’Opettajien kiinnostus oppituntien ulkopuolelle sijoittuvia opiskelijoiden toimia kohtaan", "Opettajien pyrkimys tutustua opiskelijoihin ihmisinä opettajan roolin ulkopuolella", "Opettajien osallistuminen opiskelijoiden omaehtoisesti järjestämään vapaaajan toimintaan." Nämä periaatteet tuntuvat terveen järjen mukaan ja arkihavainnonkin perusteelta tärkeiltä opettajan ja oppilaan välisen avoimen vuorovaikutussuhteen edellytyksiltä. Tässä tutkimuksessa ne kuitenkin ovat keinoja, joilla opettaja toteuttaa omia tai oppilaitoksensa kasvatustavoitteita. Esimerkki kuvannee sitä, mihin päämäärä-väline -rationaalisuuteen perustuva kasvatustilanteen tulkinta johtaa. Tämä ei tosin ole vain tämän tutkimuksen ongelma, vaan ko. tarkastelumalli on tyypillinen koko empiiris-analyyttiselle kasvatustieteelle.

Tutkimuksen tulokset on esitelty pääasiassa frekvenssitaulukkoina. Esitys on sinänsä selkeää ja johdonmukaista, mutta pääasiat - sikäli kun niitä on - katoavat erillisten tiedonjyvästen runsauteen: kahlattuaan läpi satakunta frekvenssitaulukkoa, tulee pakostakin kysyneeksi, mitä tällä tiedolla tekee.

Yleensäkin jää kysymään, mitä perusteita frekvensseinä esitetyt mielipiteet tarjoavat internaattiyhteisön kehittämiselle, etenkin kun opistokohtainen tieto on suurelta osin häivytetty kokonaisfrekvensseihin. Tutkimuksen teoreettisen perustan ja tulkintakehikon puuttuminen tekee tulosten tulkinnan ja johtopäätösten tekemisen ongelmalliseksi, lähes mahdottomaksi. Runsaasta tulosmateriaalista on perin vaikea tehdä mitään johtopäätöksiä, kun ei ole käsitystä siitä, mihin tuloksia olisi suhteutettava. Teoreettisen pohjan puuttuessa puuttuu myös tulkintahorisontti. 
Tutkimuksen tekijän puolustukseksi on sanottava, että hän on ilmeisesti tehnyt juuri sen, mitä toimeksiantaja on halunnut - ja senkin lähes niin hyvin kuin annettujen ehtojen puitteissa on ollut mahdollista.

Pauli Siljander 